\title{
Analisis Daya yang Dihasilkan Turbin Angin Tipe Windmill pada Sistem Aerasi Tambak Udang
}

\author{
Nuryanti ${ }^{1}$, Bolo Dwiartomo ${ }^{1}$, Ayi Ruswandi ${ }^{2}$ \\ ${ }^{1}$ Teknik Otomasi Manufaktur dan Mekatronik Polman Bandung \\ ${ }^{2}$ Teknik Perancangan Manufaktur Polman Bandung \\ Email:nuryanti@polman-bandung.ac.id
}

\begin{tabular}{|c|c|}
\hline Informasi Artikel: & ABSTRAK \\
\hline $\begin{array}{l}\text { Received: } \\
2 \text { Januari } 2019\end{array}$ & $\begin{array}{l}\text { Turbin angin tipe windmill yang diterapkan pada sistem Aerasi tambak } \\
\text { udang digunakan untuk memompa udara ke dalam air. Aliran udara yang } \\
\text { masuk digunakan untuk meniaga kadar oksigen di dalam air minimal } 4\end{array}$ \\
\hline $\begin{array}{l}\text { Accepted: } \\
4 \text { Maret } 2019\end{array}$ & $\begin{array}{l}\text { ppm sehingga udang yang dibudidayakan dapat berkembang dengan baik. } \\
\text { Penggunaan kompresor } 2 \mathrm{~kW} \text { dengan energi listrik dari PLN pada sistem } \\
\text { aerasi akan dikombinasi dengan energi listrik terbarukan dimana tempat }\end{array}$ \\
\hline $\begin{array}{l}\text { Available } \\
1 \text { Desember } 2019\end{array}$ & $\begin{array}{l}\text { lokasi budidaya udang memiliki potensi angin dengan kecepatan } 0.14 \text { - } \\
8.33 \mathrm{~m} / \mathrm{s} \text {. Oleh karena itu telah dirancang dan dibangun sebuah turbin } \\
\text { angin skala lapangan dengan diameter } 235 \mathrm{~cm} \text { dengan } 14 \text { bilah yang } \\
\text { disambungkan ke } 6 \text { buah pompa udara paralel dengan panjang stroke } 4 \\
\mathrm{~cm} \text {. Dari hasil pengukuran kecepatan angin dan kecepatan putar turbin } \\
\text { maka dihasilkan Tip Speed Ratio (TSR) sebesar } 0.9 \text { dimana Coefisient } \\
\text { Performance (CP) yang diperoleh } 0.31 \text {. Dari CP tersebut didapat daya } \\
\text { Energi angin yang berkorelasi dengan potensi rentang kecepatan angin } \\
\text { sebesar } 2.2 \mathrm{~mW}-462 \mathrm{~W} \text {. Jika dikombinasikan dengan kompresor } 2 \mathrm{KW} \\
\text { dari listrik PLN maka energy yang dapat dihemat bisa mencapai } 23 \% \text { / } \\
\text { turbin angin }\end{array}$ \\
\hline
\end{tabular}

\section{Kata Kunci:}

Turbin angin tipe Windmill multiblade; Coeficient of Performance; Tip speed ratio

\section{ABSTRACT}

The Windmil type of Wind Turbine has been developed for aeration system in shrimp developing farm for keeping oxygen concentration equal or above $4 \mathrm{ppm}$. Wind Turbine would be combined with $2 \mathrm{~kW}$ Compressor in order to reduce electric utilities. There are wind energy potential in the location whose wind speed in the range of $0.14-8.33$ $\mathrm{m} / \mathrm{s}$. Six parallel air pumps were attached to wind turbine with stroke length $4 \mathrm{~cm}$. From measurement result Tip Speed Ratio (TSR) 0.9 and Coefficient of Performance 0.31. From this number the power of wind turbine would be defined as $2.2 \mathrm{~mW}-462 \mathrm{~W}$. If those turbined was combined with $2 \mathrm{~kW}$ compressor, electrical utilities would be reduce until $23 \%$ for each turbine 


\section{PENDAhULUAN}

Energi angin sebagai salah satu sumber energi di alam yang berlimpah merupakan salah satu sumber energi terbarukan yang telah banyak dikembangkan sejak pertamakali di Denmark tahun 1970 hingga saat ini [1]. Energi angin yang ditangkap oleh turbin angin dengan berbagai bentuk bilah baik dengan tipe horizontal dimana bilah berputar pada sumbu horizontal, tipe vertical dimana bilah bergerak pada sumbu tegak dan tipe getar. Namun kebanyakan turbin angin yang dikembangkan adalah turbin yang mengubah energi kinetik angin menjadi energi elektrik. Seperti yang telah dilakukan oleh Rehman dan Sahin yang mengembangkan turbin angin skala kecil di Arab Saudi memberikan energi elektrik 1-10 kW pada pompa untuk mengalirkan air [2]. Hanya sedikit yang menggunakan energi mekanik angin untuk menggerakkan pompa dimana terjadi perubahan energi kinetik angin menjadi energi mekanik pompa.

Pompa udara yang dapat dimanfaatkan untuk memberikan tambahan oksigen atau disebut juga Aerasi pada tambak-tambak budidaya udang yang terletak di pinggir pantai. Sebagaimana kita ketahui daerah pinggir pantai memiliki sumber angin laut yang dapat dimanfaatkan untuk keperluan aerasi. Aerasi diperlukan bagi keberlangsungan hidup udang yang terganggu jika kadar oksigen di dalam air berkurang yaitu dibawah $5 \mathrm{ppm}$. Kadar oksigen berkurang salah satunya karena meningkatnya temperature air [3], karena pada temperature tinggi maka ikan atau udang membutuhkan lebih banyak oksigen untuk metabolismenya sehingga pada siang hari sistem aerasi sangat penting untuk digunakan. Masalah kritis pada turbin angin yang digunakan untuk menggerakkan pompa udara adalah bagaimana mengubah gerakan putar menjadi gerakan linier. Karena pompa udara hanya membutuhkan gerakan linier maju mundur untuk mendorong udara masuk ke dalam air.

Sedangkan untuk lebih memudahkan oksigen berdifusi ke dalam air maka digunakan diffuser aerator yang ditanam di dasar kolam sehingga gelembung-gelembung oksigen dapat mengalir dari dasar kolam ke permukaan kolam. Jika sebelumnya pompa aerator menggunakan energi listrik dari PLN maka dengan adanya turbin angin ini dapat mengurangi penggunaan energi listrik. Hal tersebut seperti telah dikembangkan bahkan telah menjadi produk standar dengan brand Eagle Windmill ${ }^{1}$ dan Koenders Windmill ${ }^{2}$.Namun Eagle dan Koenders Windmill menggunakan pompa diafragma untuk memompa udara ke dalam kolam. Selain itu ada juga pengembangan sistem Aerasi dengan menggunakan energi elektrik dari Turbin angin yang dikombinasi dengan solar panel untuk menyalakan pompa udara yang juga sudah dikomersilkan namun kadar difusi oksigen nya masih kecil yaitu di bawah 4 ppm [3]. Sedangkan di dalam negeri juga telah dikembangkan Aerator berbasis tenaga angin seperti yang dikembangkan oleh Yaumil Abadi $^{3}$ dan juga Ahmad Farid [7], namun keduanya menggunakan turbin vertikal berskala kecil.

Pengembangan pada penelitian ini adalah modifikasi pada baling-baling horizontal yang berbeda dengan turbin angin yang dikeluarkan oleh Eagle maupun Koenders. Dan juga berbeda dari Yaumil Abadi maupun Ahmad Farid karena keduanya menggunakan turbin angin vertical sedangkan yang akan dikembangkan dan diteliti adalah turbin horizontal. Turbin horizontal memiliki keunggulan kestabilan aerodinamis dan aliran udara yang seragam pada rotor sehingga torsi yang dihasilkan relative konstan [8]. Turbin angin untuk sistem aerasi yang akan dikembangkan memiliki poros dengan posisi blade bisa diubah-ubah dan ringan dengan momen inersia kecil sehingga diharapkan dapat berputar meski

\footnotetext{
${ }^{1}$ http://www.paulfishfarms.com/windmillaerator.htm

2 https://www.koenderswindmills.com

${ }^{3}$ http://yaumilabadi.com
} 
kecepatan rendah. Sedangkan posisi blade yang bisa dirubah-rubah dapat dicari sudut optimal dalam menangkap angin.

\section{METODOLOGI PENELITIAN}

Tahapan penelitian ini meliputi desain sistem mekanik, pembuatan dan instalasi beserta uji cobanya yang berdasarkan pada efisiensi penangkapan energi angin yang kemudian ditransfer menjadi energi mekanik yang digunakan untuk menggerakkan pompa diffuser aerator. Sistem penangkapan energi angin bertumpu pada desain baling-baling dimana energi mekanik output yang diinginkan adalah kecepatan rendah namun Torsi besar dikarenakan untuk menggerakkan pompa. Adapun Metodologi dalam tahapan ini adalah terlihat pada Gambar 1.

Pertama adalah studi literatur baik yang berasal dari buku-buku referensi, jurnal, maupun paten. Dengan berdasarkan pada referensi maka akan diperoleh parameter-parameter untuk mendesain Turbin angin beserta dengan sistem mekanik diffuser aerator yang terdiri dari Pompa, kopling poros turbin dan pompa, saluran udara dan diffuser. Kemudian Studi komparasi dengan produk sejenis di pasaran dalam hal desain, pada tahap pengujian turbin angin dan penyetingan adalah tahapan pengujian untuk menghasilkan energi mekanik dari energi kinetik angin yang ditangkap. Tahap pengujian sistem aerator, yaitu komponen turbin angin dipasangkan dengan komponen pompa udara yang telah ada. 

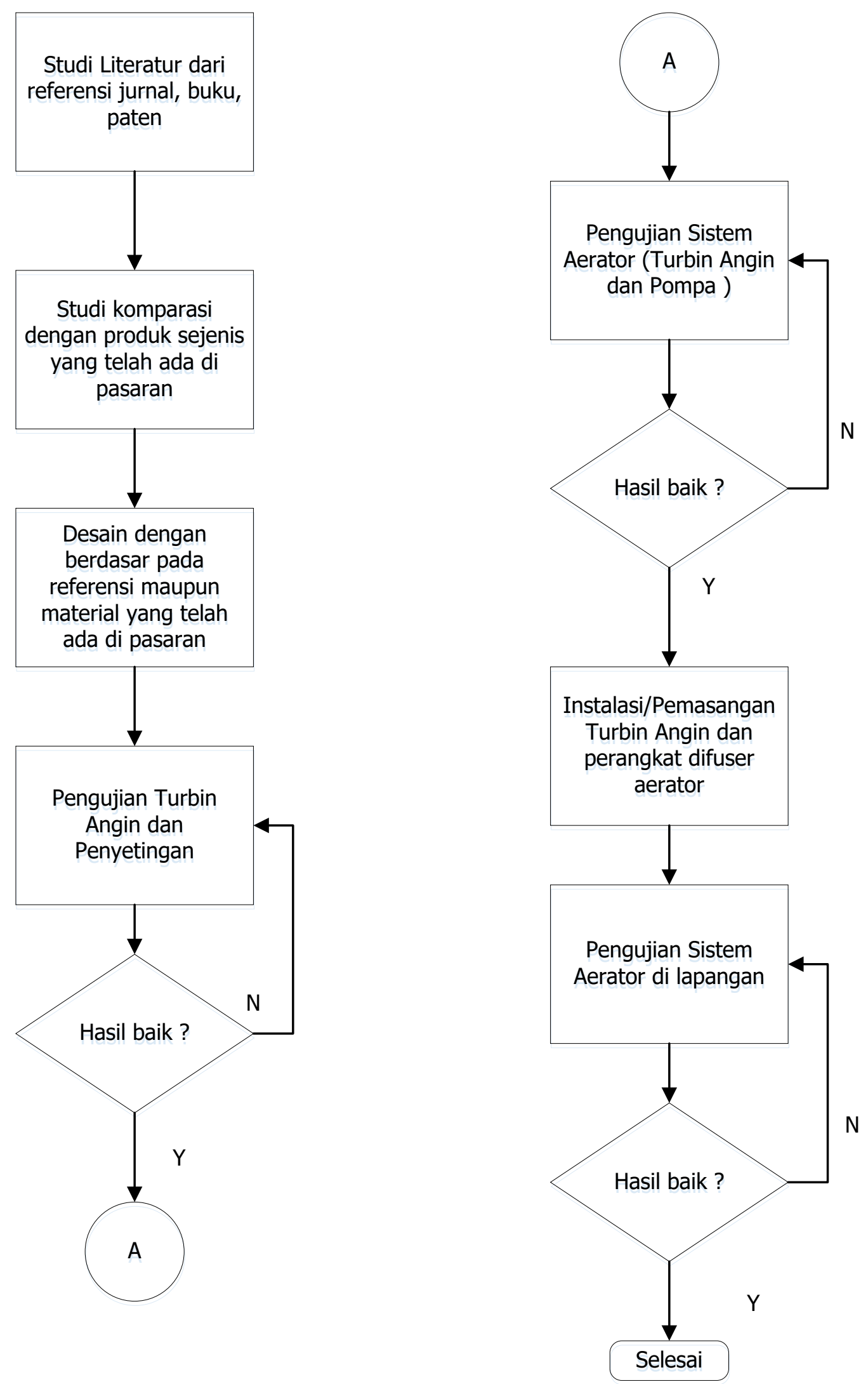

Gambar 1. Metodologi Penelitian Pengembangan Wind Turbin Aerator 


\subsection{PERANCANGAN SISTEM}

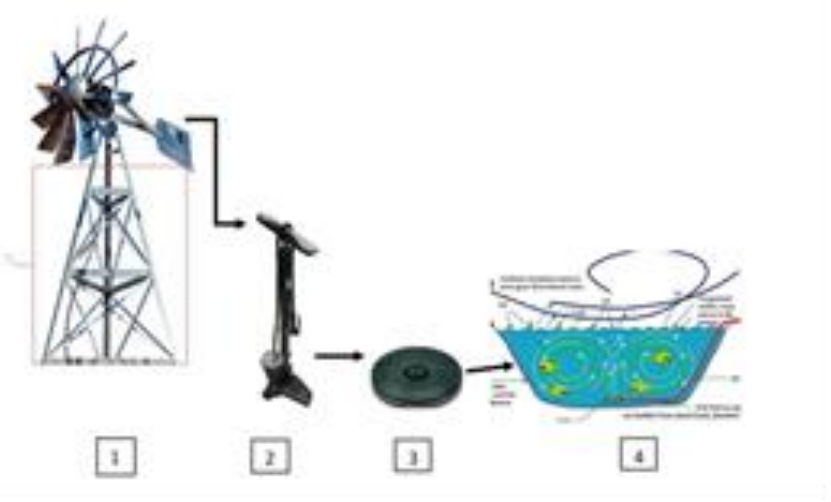

Gambar 2. Sistem Aerator dengan menggunakan Turbin Angin tipe Windmill/Windfarm

Sistem Aerasi dengan menggunakan turbin angin terdiri dari turbin angin (1) sebagai sumber energi kinetik yang akan menggerakkan pompa udara (2).Gerakan memutar pada turbin angin akan dikonversi menjadi gerakan turun naik pompa udara. Pompa udara akan menghisap udara dari luar dan memasukkan ke dalam air. Udara ini akan disebar oleh difuser (3) sehingga berbentuk gelembung-gelembung kecil. Difuser nantinya akan diletakkan di dasar kolam (4) sesuai dengan kebutuhan oksigen yang diperlukan oleh udang agar tumbuh optimal.

Pompa seperti yang diperlihatkan pada Gambar 3 dimana proses menghisap dan mendorong digerakkan secara mekanik oleh Roda Eksentrik maju mundur. Roda eksentrik di sini adalah roda yang dibuat tidak berbentuk bulat sempurna, atau dapat dibuat lingkaran namun poros tidak berada pada pusat lingkaran. Roda eksentrik bertujuan untuk mengubah gerakan memutar pada turbin angin menjadi gerakan naik turun pada pompa diafragma. Pada realisasi penelitian roda eksentrik seperti diperlihatkan pada Gambar 3 diletakkan sesumbu dengan Turbin Angin

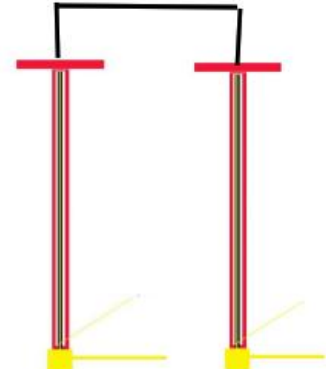

(a)

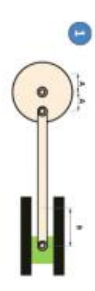

(b)

Gambar 3. Roda Eksentrik Pada Pompa Diafragma secara umum

(a) Beberapa pompa udara yang diparalel. (b) Roda eksentrik yang dihubungkan ke pompa paralel 


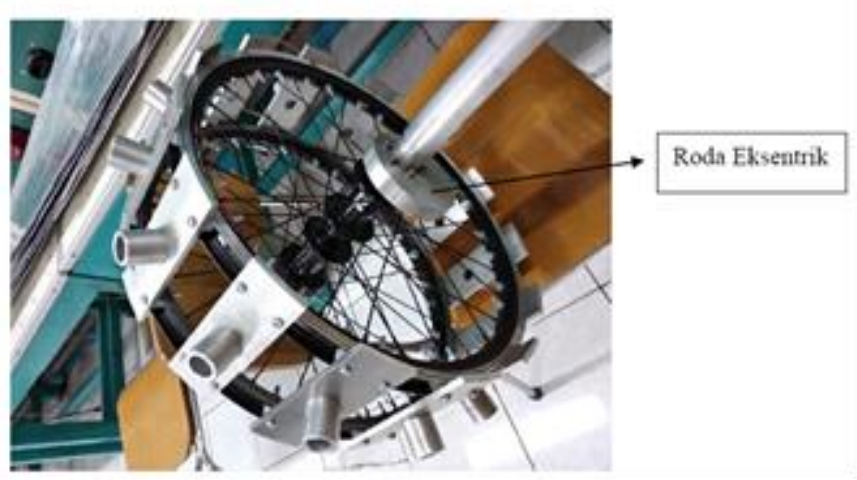

Gambar 4. Roda Eksentrik yang sesumbu dengan poros Turbin Angin

Pada perancangan sistem maka yang dilakukan pertamakali adalah mendefinisikan kebutuhan energi agar tercapai difusi oksigen minimal 4ppm. Dimana $4 \mathrm{ppm}$ itu setara dengan $4 \mathrm{mg} / \mathrm{L}$. Volume air kolam diketahui $250 \mathrm{~m} 2 \times 1.5 \mathrm{~m}=375 \mathrm{m3}$. maka massa oksigen yang terkandung dalam $375 \mathrm{~m} 3$ air kolam adalah $1500 \mathrm{~kg}$. Jika massa tersebut diperoleh dalam 24 jam, maka aliran massanya $0.01736 \mathrm{~kg} /$ detik. Pada tekanan ruang $1 \mathrm{~atm}$ ( $105 \mathrm{~Pa}$ ) dan temperature ruangan $=25+273 \mathrm{~K}=298 \mathrm{~K}, \mathrm{n}$ (mol oksigen) adalah $(0.01736 \mathrm{x}$ $1000) / 16=1.085 \mathrm{~mol} /$ detik. Maka jika oksigen yang dialirkan tergolong gas ideal maka debit gas oksigen dapat diturunkan dari persamaan gas ideal dimana $\mathrm{R}$ adalah nilai konstanta gas umum $8.31 \mathrm{~J} / \mathrm{mol}$.K maka volume per detik dapat dicari dengan menggunakan formula

$$
P x V^{\prime}=\dot{n}^{\prime} R x T
$$

sehingga diperoleh debit oksigen yaitu $0.02678 \mathrm{~m}^{3} /$ det Untuk menghasilkan debit oksigen sebesar itu dibutuhkan daya dengan perhitungan :

$$
\text { Daya }=\mathrm{P} \times \mathrm{Q}
$$

Dimana,

$\mathrm{P}=$ tekanan hidrostatik di dasar kolam dengan kedalaman $1.5 \mathrm{~m}$ (yaitu $15000 \mathrm{~N} / \mathrm{m} 2$ )

$\mathrm{Q}=0.02678 \mathrm{~m}^{3} / \mathrm{det}$

maka diperoleh daya yang dibutuhkan sebesar $403 \mathrm{~W}$. Berikut tabel daya yang dibutuhkan untuk memenuhi konsentrasi oksigen 4 ppm dengan berbagai rentang waktu. Pada Tabel 1. Daya kincir yang dibutuhkan untuk memenuhi konsentrasi oksigen dengan berbagai rentang waktu yang dibutuhkan 
Tabel 1. Daya kincir yang dibutuhkan untuk memenuhi konsentrasi oksigen dengan berbagai rentang waktu yang dibutuhkan

\begin{tabular}{lrrrr}
\hline $\begin{array}{c}\text { Rentang } \\
\text { Waktu }\end{array}$ & $\begin{array}{c}\text { Massa Oksigen } \\
\text { dalam liter air } \\
\text { (kg/L) }\end{array}$ & $\begin{array}{c}\text { laju mol } \\
\text { Oksigen } \\
\text { (mol/det) }\end{array}$ & $\begin{array}{c}\text { Debit } \\
\text { Oksigen } \\
\text { (m3/det) }\end{array}$ & \multicolumn{1}{c}{$\begin{array}{c}\text { Daya yang } \\
\text { dibutuhkan (W) }\end{array}$} \\
\hline 24 jam & 0.02 & 1.09 & 0.03 & 403.06 \\
\hline 12 jam & 0.03 & 2.17 & 0.05 & 806.11 \\
\hline 6 jam & 0.07 & 4.34 & 0.11 & 1612.23 \\
\hline Per-jam & 0.42 & 26.04 & 0.64 & 9673.36 \\
\hline 5 menit & 5.00 & 312.50 & 7.74 & 116080.31 \\
\hline Per-menit & 25.00 & 1562.50 & 38.69 & 580401.56 \\
\hline Per-detik & 1500.00 & 93750.00 & 2321.61 & 34824093.75 \\
\hline
\end{tabular}

Dalam melakukan realisasi pembuatan kincir angin yang telah didesain sebelumnya maka ada lima tahapan langkah antara lain :

\subsubsection{Perancangan dan Pembuatan Sudu Turbin Angin Real Lapangan}

Pada tahapan ini dilakukan perancangan turbin angin berdasarkan kebutuhan serta kondisi dari tempat yang akan dijadikan tempat pemasangan turbin angin. Dengan sumbu pusat putar berdiameter 14 inch dilakukan desain sudu turbin angin seperti yang ditunjukkan pada gambar 5 menunjukkan bilah kincir angin yang dibuat memiliki panjang $100 \mathrm{~cm}$, lebar root $23 \mathrm{~cm}$, dan lebar tip $15,5 \mathrm{~cm}$

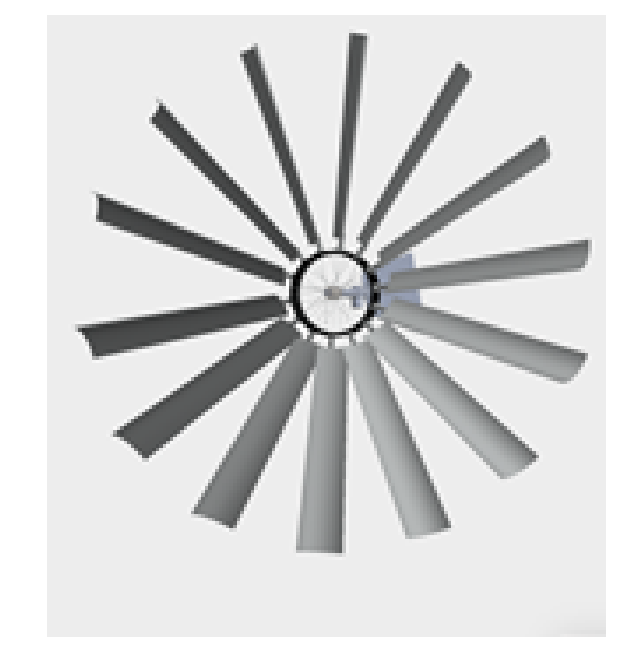

Gambar 5. Desain Sudu pada Turbin Angin

Selanjutnya adalah tahapan manufaktur berdasarkan dari desain yang sudah dibuat sebelumnya dan disesuaikan kembali dengan keadaan lapangan apabila terdapat hal yang harus direvisi dan diperbaiki. Poses Pembuatan dimulai mengukur dan memotong plat alumunium sesuai dengan desain yang sudah dirancang. Setelah proses pemotongan selesai maka selanjutnya adalah proses pengeboran untuk memasang ring yang nanti berfungsi sebagai penghubung sudu dengan hub turbin angin 


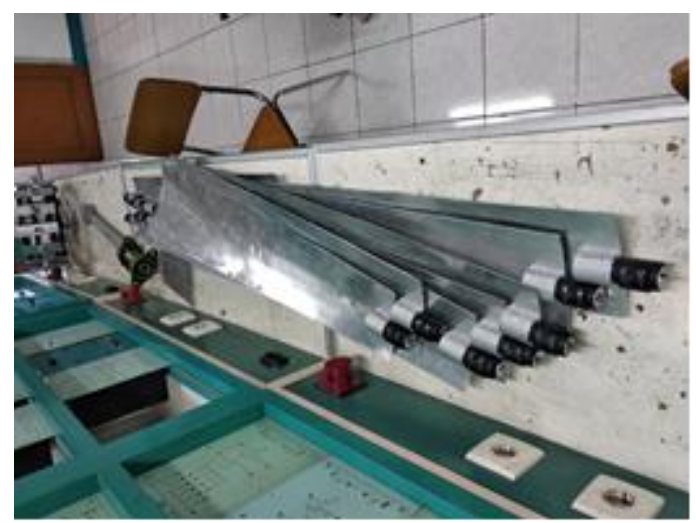

Gambar 6. Sudu yang dibuat sebanyak 14 buah

\subsubsection{Proses assembling atau perakitan sudu}

Proses pembuatan blade yang dilakukan di bengkel, kemudian perakitan dilakukan di lab.kendali dan lantai 4 roof top untuk area yang lebih luas karena kincir berukuran besar

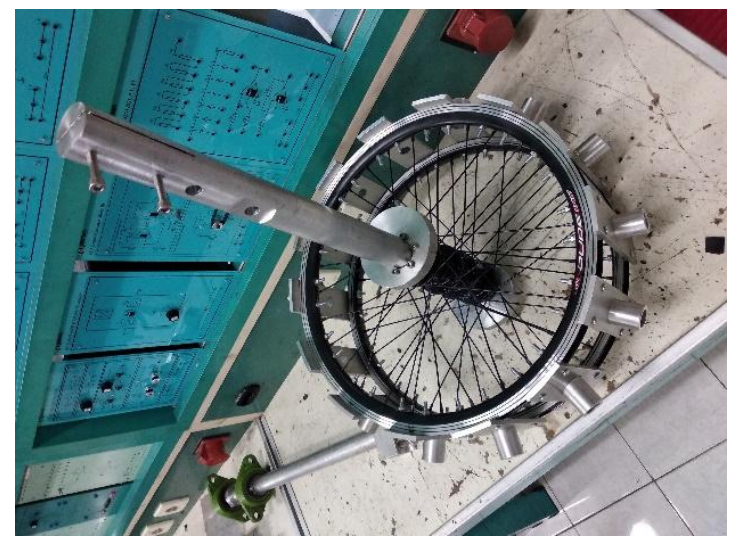

Gambar 7. Rangka hub turbin 14 inch untuk pemasangan bilah turbin

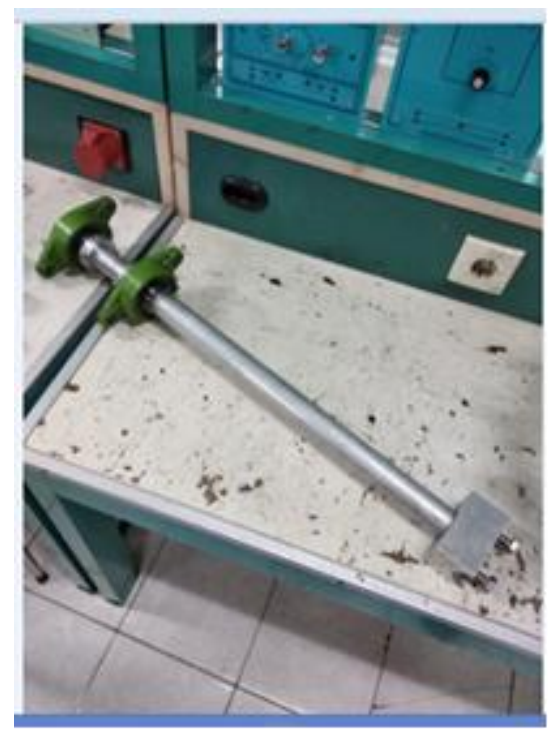

Gambar 8. Sumbu putar kincir 


\subsubsection{Perakitan penopang kincir angin}

Selain perakitan kincir angin tak kalah pentingnya yaitu perakitan penopang kincir yang terbuat dari material besi baja yang disatukan dengan menggunakan mur, sehingga memudahkan untuk dibongkar pasang. Pada Gambar 9 memperlihatkan perakitan kincir angin.

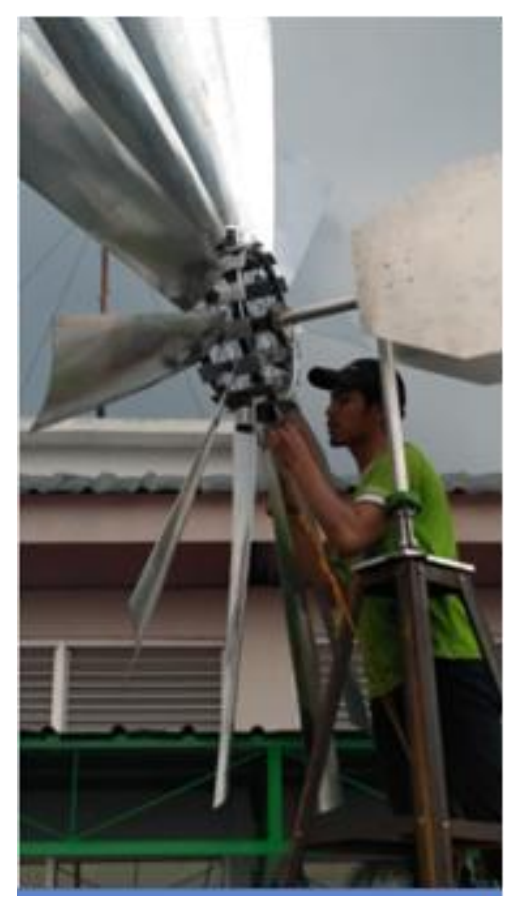

Gambar 9. Kincir yang sudah terakit dengan sempurna

\section{HASIL}

Data performansi turbin dapat diperoleh dari Tip Speed Ratio (TSR), TSR adalah perbandingan kecepatan baling-baling dengan kecepatan angin yang diformulasikan sebagai berikut :

$$
\lambda=\frac{n \cdot \pi \cdot D}{60 \cdot v_{\text {angin }}}
$$

$\lambda=$ Tip Speed Ratio

$\mathrm{n}=$ jumlah putaran turbin per-menit

$\mathrm{D}=$ diameter kincir $(\mathrm{m})$

$\mathrm{V}_{\text {angin }}=$ kecepatan angin

Diameter kincir yang dibuat $(2 \times 100) \mathrm{cm}+(2.5 \times 14) \mathrm{cm}=200+35=235 \mathrm{~cm}$

Dalam pengambilan data tip speed untuk kecepatan angin $1.54 \mathrm{~m} / \mathrm{s}$ dengan sudut blade $15^{\circ}$ dan kecepatan putar bilah 11 rpm dapat dihitung

$$
\lambda=\frac{11 \times \pi \times 2.35}{60 \times 1.54}=\frac{75.12}{92.4}=0.9
$$

Sebagai perbandingan tipspeed ratio pada turbin modern 3 blade yang ada di pasaran berkisar $5-7$ pada putaran $10-30 \mathrm{rpm}$. 
Tabel 2. Perbandingan Tip Speed Ratio Tipe Turbin Modern (Pembangkit Listrik) dan Turbin Windmill yang dibangun

\begin{tabular}{lcc}
\hline \multicolumn{1}{c}{ Tipe Turbin } & Putaran & Tip Speed Ratio \\
\hline Modern Turbin pembangkit listrik & $10-30 \mathrm{rpm}$ & $5-7$ \\
\hline Windmill yang dikembangkan dalam penelitian & $11 \mathrm{rpm}$ & 0.9 \\
\hline
\end{tabular}

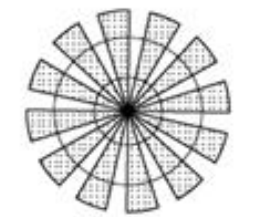

Farm Type

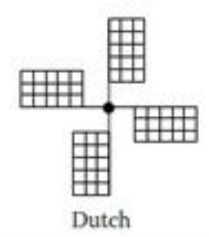

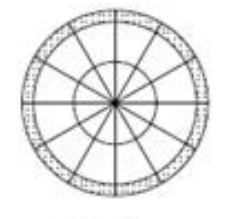

Farm Type

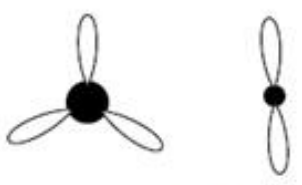

Modern Propeller

Gambar 10. Tipe Turbin Angin[1]

Di sini bisa dilihat bahwa kecepatan angin $1.54 \mathrm{~m} / \mathrm{s}$ sudah mampu membuat windmill berputar dengan kecepatan $11 \mathrm{rpm}$. Dengan tip speed ratio 0.9 dapat dicari power koefisient (CP) untuk tipe windmills berdasar pada Gambar 11 maka diperoleh nilai $\mathrm{CP}=0.31$ atau hampir maksimum untuk tipe American Multiblade. Gambar 11 memperlihatkan variasi koefisien performansi dari berbagai jenis tipe turbin angin sebagai fungsi tip speed ratio.

Tipe turbin angin yang dikembangkan adalah tipe windmill atau American Multiblade yang cenderung memang memiliki tip speed ratio rendah dan koefisien performansi rendah juga dibandingkan dengan tipe propeler dan tipe 2 bilah (high speed two blade type). Pada tipe American multiblade Koefisien Performansi maksimum sekitar 0.32 pada tip speed ratio sekitar 0.8. Tapi untuk tipe American multiblade ini masih memiliki koefisien performansi yang lebih baik dibandingkan dengan Savonius Rotor ataupun model Dutch Four Arm.

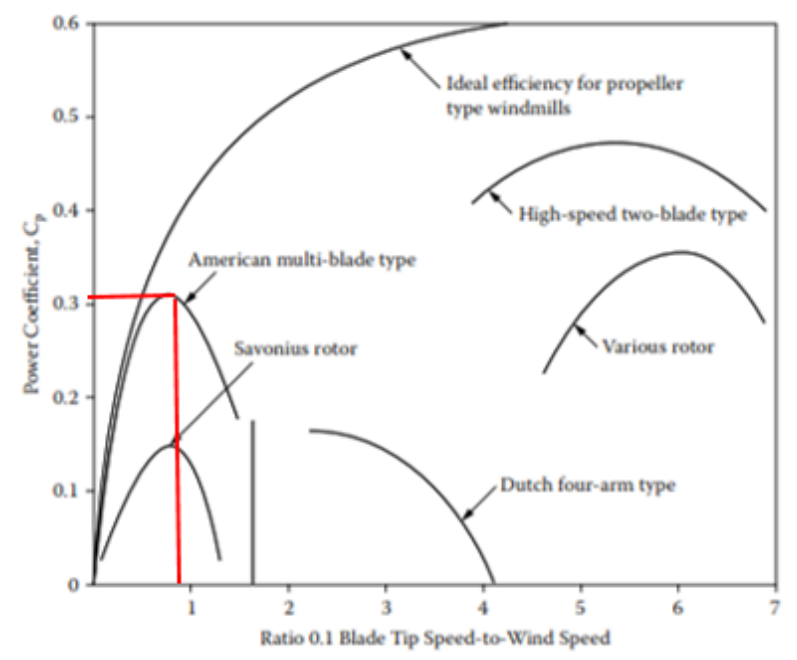

Gambar 11. Hubungan antara Koefisient Performansi dan Rasio Tip Speed [1] 
Daya yang diberikan oleh angin dapat dihitung dengan menggunakan rumus :

$$
P_{\text {delivered }}=C_{p} \cdot \frac{1}{2} \rho A v^{3}
$$

Jika Luas permukaan turbin (Diameter $235 \mathrm{~cm}$ ) $=3.14 \times 117.5^{2} \mathrm{~cm}=43352 \mathrm{~cm}^{2}=4.3 \mathrm{~m}^{2}$, , kecepatan angin di pantai Cianjur Selatan dimana turbin angin ini akan dipasang menurut data BMKG antara $0.14-8.33 \mathrm{~m} / \mathrm{s}$ dan masa jenis udara pada temperature $27^{\circ}=1.2 \mathrm{~kg} / \mathrm{m}^{3}$, maka daya turbin yang dihasilkan adalah :

$$
\begin{gathered}
P_{\text {min }}=0.31 \times \frac{1}{2} \times 1.2 \times 4.3 \times 0.14^{3}=2.2 \mathrm{~mW} \\
P_{\text {max }}=0.31 \times \frac{1}{2} \times 1.2 \times 4.3 \times 8.33^{3}=462.3 \mathrm{~W}
\end{gathered}
$$

Dengan demikian daya yang dihasilkan oleh turbin angin yang dikembangkan adalah $2.2 \mathrm{~mW}$ $-462.3 \mathrm{~W}$. Daya $2.2 \mathrm{~mW}$ sangat kecil sehingga yang digunakan adalah kecepatan angin $8.33 \mathrm{~m} / \mathrm{s}$ dengan daya $462.3 \mathrm{~W}$. Jika kebutuhan aerasi untuk memperoleh oksigen 4ppm untuk masa inisiasi pengisian selama 24 jam diperlukan daya sebesar $403 \mathrm{~W}$, maka 1 turbin angin cukup untuk menyuplai kebutuhan tersebut.

Namun untuk inisiasi pengisian yang lebih singkat maka turbin angin yang diperlukan makin banyak. Tabel 2 menunjukkan banyaknya turbin angin yang dibutuhkan pada sistem aerasi dengan berbagai variasi rentang waktu. Untuk pengisian kadar oksigen yang semakin cepat jika hanya mengandalkan turbin angin maka jumlahnya akan sangat banyak.

Oleh karena itu posisi turbin angin di sini tidak menggantikan energi yang sebelumnya yaitu pompa aerasi dengan listrik dari PLN, melainkan mengurangi pemakaian pompa aerasi terutama saat angin bertiup kencang. Atau dapat dikombinasikan dengan sumber energi terbarukan yang lain yaitu solar sel.

Jika sistem aerasi yang telah ada saat ini masih menggunakan kompresor listrik dari PLN dengan daya $2 \mathrm{KW}$, dimana bekerja untuk menjaga kadar oksigen tetap pada level 4 ppm,maka dengan kombinasi turbin angin windmill ini penghematan yang dapat dilakukan dapat dihitung dari Daya Kincir / 2KW misal pada daya kincir sebesar 462W maka penghematan yang dapat dilakukan $(462 / 2000) * 100 \%=23 \%$.

Jadi sebesar 23\% energi dari PLN dapat digantikan dengan 1 unit turbin angin pada sistem aerasi. Penghematan dapat pula dilakukan hingga 100\% atau menggantikan kompresor dengan energy angina maka jumlah unit turbin angina yang dibutuhkan sekitar 5 unit. Namun penghematan energi jika diikuti dengan penambahan jumlah turbin angin yang biaya investasinya juga tidak sedikit maka akan dilakukan optimasi berikutnya sehingga diperoleh biaya yang optimal untuk level penghematan tertentu. 
Tabel 3. Hubungan Kecepatan Angin dengan Energi yang dihasilkan untuk kecepatan angin $8.33 \mathrm{~m} / \mathrm{s}$

\begin{tabular}{|c|c|c|}
\hline Jumlah Turbin angin (unit) & $\begin{array}{l}\text { Maksimum energy yang dihasilkan } \\
\text { (W) }\end{array}$ & Penghematan Energi (\%) \\
\hline 1 & 462 & 23.1 \\
\hline 2 & 924 & 46.2 \\
\hline 3 & 1386 & 69.3 \\
\hline 4 & 1848 & 92.4 \\
\hline 5 & 2310 & 115.5 \\
\hline
\end{tabular}

\section{KESIMPULAN}

Turbin angin tipe Windmill atau American Multiblade yang telah dibuat memiliki tip speed ratio 0.9. Koefisien performansi Turbin angin yang dikembangkan 0.31 atau hampir maksimum untuk tipe American Multiblade. Pada kecepatan angin antara $0.14-8.33 \mathrm{~m} / \mathrm{s}$ daya yang dihasilkan mencapai $2.2 \mathrm{~mW}-462.3 \mathrm{~W}$. Dengan kecepatan angin $8.33 \mathrm{~m} / \mathrm{s}$ maka 1 unit turbin angin dapat melakukan penghematan energi kompresor dari PLN sebesar $20 \%$, dan untuk menggantikan kompresor $100 \%$ maka dibutuhkan hingga 5 unit turbin angin.

\section{REFERENSI}

[1] A.R Jha,PHD, Wind Turbine Technology, CRC Press Taylor and Francis Group, US 2011

[2] Shafiqur Rehman, Ahmet Z Sahin, "Wind Power Utilization for Water Pumping Using Small Wind Turbines in Saudi Arabia : A Techno Economical Review", Renewable and Sustainable Energi Reviews 16, 2012, pp 4470-4478

[3] Emily Hoopman, "A Comparison of Commercial Aeration System in Northern Wisconsin Aquaculture Ponds ", Bayfiel High School Research, 2012

[4] Windmill Aeration System, http://www.paulfishfarms.com/windmillaerator.htm

[5] World's Leading Water Aeration, https://www.koenderswindmills.com

[6] Aerator Turbin Angin Untuk Tambak Masa Depan, http://yaumilabadi.com/

[7] Ahmad Farid, Analisa Daya Turbin Angin Poros Vertikal Sebagai Aerator Tambak, Jurnal Akprin, 2016

[8] Kung-Yen Lee Shao-Hua Tsao, Chieh-Wen Tzeng, Huei-Jeng Lin, "Influence of the vertical wind and wind direction on the power output of a small vertical-axis wind turbine installed on the rooftop of a building", Applied Energi Journal, Elsevier, 2017 